\title{
Implementasi Metode Talaqqi dalam Menghafal Alquran
}

\author{
Sania' ${ }^{1}$, Ahmad Kosasih ${ }^{2}$ \\ saniania1007@gmail.com ${ }^{1}$, ahmadkosasihtanjung@gmail.com² \\ Universitas Negeri Padang ${ }^{1,2}$
}

\begin{tabular}{|c|c|}
\hline ARTICLE INFO & ABSTRAK \\
\hline Article history: & \multirow{11}{*}{$\begin{array}{l}\text { This research was motivated by an interest in the } \\
\text { implementation of the talaqqi method in memorizing the } \\
\text { Qur'an at TPQ Baitul Rahmah Simpang III Patangan. This } \\
\text { study aims to examine the implementation of the talaqqi } \\
\text { method in memorizing the Koran, evaluating the talaqqi } \\
\text { method in memorizing the Koran, and the inhibiting and } \\
\text { supporting factors of the talaqqi method in memorizing the } \\
\text { Koran. The method used in this research is qualitative } \\
\text { research with a descriptive analysis approach and using } \\
\text { field studies. The results showed that: First, the } \\
\text { implementation of the talaqqi method was carried out by } \\
\text { way of the students sitting in a circle and the teacher } \\
\text { conveying directly to the students about the verse or letter } \\
\text { that would be memorized correctly. Second, the evaluation } \\
\text { of the talaqqi method was carried out without the } \\
\text { knowledge of the students and was called randomly. Third, } \\
\text { the inhibiting factor of the talaqqi method at TPQ Baitul } \\
\text { Rahmah Simpang III Palanggaran, namely the students who } \\
\text { feel bored while waiting in line because of the individual } \\
\text { memorization deposits, the supporting factor for the talaqqi } \\
\text { method at TPQ Baitul Rahmah Simpang III Palanggaran, } \\
\text { namely the high interest of the students to learn the Qur'an. }\end{array}$} \\
\hline $\begin{array}{l}\text { Received, } 21 \text { Oktober } \\
2021\end{array}$ & \\
\hline $\begin{array}{l}\text { Revised, } 18 \text { November } \\
2021\end{array}$ & \\
\hline $\begin{array}{l}\text { Accepted, } 28 \text { Februari } \\
2022\end{array}$ & \\
\hline Keywords: & \\
\hline $\begin{array}{l}\text { Menghafal Alquran, } \\
\text { Metode, Talaqqi }\end{array}$ & \\
\hline & \\
\hline Conflict of Interest: & \\
\hline None & \\
\hline Funding: & \\
\hline None & \\
\hline
\end{tabular}

Corresponding Author: Sania, Department Islamic Education Faculty of Social Science Universitas Negeri Padang, Indonesia, Email: saniania1007@gmail.com Phone No: $+6282286443823$

\section{Pendahuluan}

Menghafal Alquran ialah aktivitas menghayati serta meresapkan bacaan-bacaan Alquran kedalam hati sampai menempel kokoh dalam ingatan. Kegiatan menghafal Alquran menempati tingkatan paling tinggi dibanding hanya membaca serta mendengar sebab terhimpun tiga kegiatan sekaligus ialah membaca, mengulang bacaan, serta menyimpan dalam memori otak. Kegiatan menghafal Alquran sangat erat kaitannya dengan metode, yaitu metode menghafal Alquran. Pengertian sederhana mengenai apa itu metode adalah cara atau jalan yang telah teratur dan berpikir baik-baik untuk mencapai suatu maksud yang diinginkan (Poerwadarminta,1999:767).

Salah satu metode yang digunakan dalam menghafal Alquran adalah metode 
Sania dan Ahmad Kosasih: Implementasi Metode Talaqqi dalam Menghafal...

talaqqi. Metode talaqqi adalah cara guru menyampaikan bacaan Alquran secara musyafahah (anak melihat gerak bibir guru secara tepat) yaitu berhadapan langsung dengan murid dalam posisi duduk dengan tenang dan nyaman, kemudian guru membimbing anak untuk mengulang-ulang ayat yang dibacakan dan diperdengarkan kepada anak sampai anak benar-benar hafal ayat yang dibacakan (Imana,2009:7).

Taman pendidikan Alquran (TPQ) adalah salah satu lembaga atau kelompok masyarakat yang menyelenggarakan pendidikan non-formal jenis keagamaan Islam yang bertujuan untuk memberikan pengajaran Alquran, serta memahami dasardasar ilmu islam. Salah satu TPQ yang mengajarkan seni baca tulis Alquran yaitu TPQ Baitul Rahmah Simpang III Palanggaran. TPQ Baitul Rahmah tidak hanya mengajarkan seni baca tulis Alquran saja tetapi juga mengajarkan tentang cara sholat yang benar, berpidato, menghafal Alquran dan lain sebagainya. Pada tahun ini beberapa peserta didik di TPQ Baitul Rahmah diterima di Sekolah Menengah Pertama dan Madrasah Tsanawiyah favorit.

TPQ Baitul Rahmah Simpang III Palanggaran Kabupaten Padang Pariaman melaksanakan metode talaqqi dalam menghafal Alquran, metode ini sudah dilakukan kurang lebih 4 tahun. Berdasarkan observasi awal peneliti pada hari Rabu 10 Februari 2021 di TPQ Baitul Rahmah Simpang III Palanggaran bahwasanya salah satu alasan penerapan metode talaqqi dalam menghafal Alquran ialah penerapan metode yang mudah digunakan oleh murid serta efektif dalam pelaksanaanya. Hal ini disebabkan adanya beberapa siswa yang masih belum mahir, sebagian terbata-bata, dan sebagian lainnya melakukan kesalahan dalam pengucapan huruf hijaiyah sehingga huruf yang dibacakan tidak sesuai dengan artinya.Peneliti mengamati bahwa kemampuan dalam menghafal Alquran peserta didik harus ditingkatkan dan memerlukan metode yang tepat dalam memacu peserta didik untuk meningkatkan kemampuan menghafal Alquran.

\section{Tinjauan Pustaka}

Menghafal Alquran dalam kamus bahasa arab kata menghafal berasal dari kata hafidza-yahfadzu- hifdzan yang berarti memelihara, menjaga, menghafal (Yunus,2007:107). Dalam kamus besar Bahasa Indonesia, menghafal adalah berusaha meresapkan kedalam fikiran agar selalu ingat. Sedangkan menghafal pada dasarnya merupakan bentuk atau bagian dari proses mengingat yang mempunyai pengertian menyerap atau melekatkan pengetahuan dengan jalan pengecaman secara aktif. Dalam Alquran Allah memerintahkan umatnya supaya memelihara Alquran yang terdapat dalam surat Al-Hijr ayat 9 yang artinya "Sesungguhnya Kamilah yang menurunkan Alquran, dan pasti Kami pula yang memeliharanya."

Surat Al-Hijr ayat 9 menjelaskan bahwa kita sebagai umat muslim harus memelihara Alquran karena Alquran adalah kalamullah atau firman Allah yang diturunkan kepada Nabi Muhammad SAW dan dipandang beribadah bila membacanya (Supandi, 2014:3). Sedangkan menurut Ash-Shaabuniy, Alquran adalah kalamullah yang tiada tandingannya (mukjizat), diturunkan kepada nabi Muhammad SAW, penutup para nabi dan rasul dengan perantara Malaikat Jibril dimulai dengan surat Al-Fatihah dan diakhiri dengan surat Al-Nash, dan ditulis dalam mushafmushaf yang disampaikan kepada seluruh manusia secara mutawatir (oleh orang banyak), serta mempelajarinya merupakan suatu ibadah (Shaabuniy,1998:15). 
Metode dalam bahasa arab dikenal dengan istilah thariqoh yang berarti langkahlangkah strategis yang dipersiapkan untuk melakukan sesuatu pekerjaan. Kata metode berasal dari bahasa latin dan juga yunani, methodus yang berasal dari kata meta yang berarti sesudah atau diatas, dan kata hodos yang berarti suatu jalan atau suatu cara. Metode adalah cara yang telah teratur dan berpikir baik-baik untuk mencapai suatu maksud yang diinginkan (Poerwadarminta,1999:767).

Selanjutnya Ahmad Tafsir (1995:9), juga mendefinisikan bahwa metode ialah istilah yang digunakan untuk mengungkapkan pengertian "cara yang paling tepat dan cepat dalam melakukan sesuatu. Ungkapan "paling tepat dan cepat" itulah yang membedakan method dengan way (yang juga berarti cara) dalam bahasa Inggris". Menurut Zulkifli (2011:6), metode adalah cara yang dapat digunakan untuk mengimplementasikan rencana yang sudah disusun dalam bentuk kegiatan nyata dan praktis untuk mencapai tujuan pembelajaran. Sehingga metode juga bisa diartikan sebagai cara mengerjakan sesuatu. Dan cara itu mungkin baik, tapi mungkin tidak baik. Baik dan tidak baiknya suatu metode tergantung kepada beberapa fakto dimana faktor-faktor tersebut mungkin berupa situasi dan kondisi serta pemakaian dari suatu metode tersebut.

Talaqqi menurut bahasa berasal dari kata talaqqa-yatalaqqa asal dari fiillaqiyayalqa-liqaan yang berarti adalah bertemu, berhadapan, mengambil menerima. Sedangkan menurut istilah talaqqi adalah metode yang diajarkan malaikat Jibril kepada Rasullullah SAW, talaqqi adalah suatu metode mengajarkan Alquran secara langsung, artinya pengajaran Alquran itu diterima dari generasi ke generasi, dari seorang guru yang mengajarkan secara langsung dari mulut kemulut kepada muridnya. Oleh karena itu, dengan cara ini maka rangkaian sanad (silsilah guru) akan menjadi jelas bersambung sehingga sampai kepada Rasulullah SAW. (Wijaya,2008:288).

Metode ini terbukti paling lengkap dalam mengajarkan bacaan Alquran yang benar, dan paling mudah diterima oleh semua kalangan. Metode ini menjadi bukti historis keaslian Alquran yang bersumber dari Allah SWT (Qawi,2017:269). Talaqqi dari segi bahasa diambil dari pada perkataan yaitu belajarsecara berhadapan dengan guru. Sering pula disebut musyafahah, yang bermakna dari mulut ke mulut (pelajar belajar Alquran dengan memperhatikan gerak bibir guru untuk mendapatkan pengucapan makhraj yang benar).

Dalam Alquran Allah SWT berfirman dalam Q.S Qaf: 17:

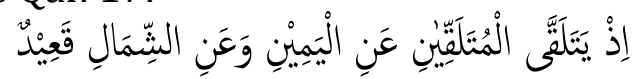

Artinya: "(Ingatlah) ketika dua malaikat mencatat (perbuatannya), yang satu duduk di sebelah kanan dan yang lain di sebelah kiri."

Dalam tafsir Jalalayn menafsirkan surat Qaf ayat 17 yaitu (Ingatlah ketika) lafal Idz di sini dinashabkan oleh lafal Udzkur yang keberadaannya diperkirakan (mencatat) yakni menulis (dua malaikat pencatat amal) artinya, yang diserahi tugas oleh Allah untuk mencatat amal perbuatan yang dilakukan oleh manusia (yang satu berada di sebelah kanan dan yang lain berada di sebelah kiri) manusia (dalam keadaan duduk) yakni keduanya duduk, lafal $Q a^{\prime}$ iid ini adalah Mubtada dan Khabarnya adalah lafal sebelumnya. 
Sania dan Ahmad Kosasih: Implementasi Metode Talaqqi dalam Menghafal...

\section{Metode}

Metode yang dipakai dalam penelitian ini adalah penelitian kualitatif dengan menggunakan metode analisis deskriptif. Penelitian yang dilakukan oleh penulis termasuk dalam kategori studi lapangan (field research). Informan dalam penelitian ini ialah guru dan santri TPQ Baitul Rahmah Simpang III Palanggaran Kabupaten Padang Pariaman. Pengumpulan data yang diperlukan penelitian ini menggunakan teknik observasi dan wawancara. Ketepatan dan kebenaran data yang sudah berhasil digali, dikumpulkan dan dicatat dalam kegiatan penelitian harus dipastikan dengan baik. Untuk menguji kredibilitas dan pengecekan data, maka diperlukan teknik pemeriksaan. Terdapat beberapa teknik yang digunakan dalam pengecekan keabsahan temuan di antaranya yaitu perpanjangan keikutsertaan, ketekunan pengamamatan, dan triangulasi.

\section{Hasil dan Pembahasan}

\section{Pelaksanaan Metode Talaqqi dalam Menghafal Alquran di TPQ Baitul Rahmah Simpang III Palanggaran}

Untuk mengetahui pelaksanaan metode talaqqi dalam menghafal Alquran di TPQ Baitul Rahmah Simpang III Palanggaran Kabupaten Padang Pariaman, pembaca mengawali penelitian dengan melakukan wawancara (interview). Pertama pembaca mewawancarai salah seorang guru di TPQ Baitul Rahmah Simpang III Palanggaran yang bernama Ibu Verawati. Kemudian pembaca mewawancarai guru dan santri di TPQ Baitul Rahmah Simpang III Palanggaran. Selanjutnya pembaca juga melakukan observasi kelokasi penelitian TPQ Baitul Rahmah Simpang III Palanggaran pada saat berlangsungnya kegiatan mengaji di TPQ tersebut, yaitu dengan tujuan untuk mengetahui dan mengamati bagaimana proses pelaksanaan metode talaqqi di TPQ Baitul Rahmah Simpang III Palanggaran Kabupaten Padang Pariaman. Proses pelaksanaan pembelajaran di TPQ Baitul Rahmah Simpang III Palanggaran dilaksanakan setiap hari Senin sampai Jum'at dari jam 16.00 - 18.00 WIB, pada hari Ahad dilaksanakan didikan subuh dari jam 05.30 WIB sampai selesai.

Qawi (2017) mengatakan bahwa langkah-langkah dalam metode talaqqi yaitu sebagai berikut:

1) Guru serta murid saling berhadapan

2) Murid menyetorkan hafalan yang sudah dihafalkan

3) Guru memperhatikan bacaan ayat-ayat sang murid dengan teliti

4) Pada saat mengalami kekeliruan, guru langsung berikan kode "Ehm" ataupun berikan kode dengan ketukan

5) Guru memancing bacaan dengan bunyi awal ayatnya bila sang murid lupa

6) Guru memperbaiki bacaan bila makharojul hurufnya masih keliru

7) Guru membaca ulang ayat yang benar sesuai tartil

8) Murid mengulangi bacaan ayatnya sesuai kemampuannya

9) Apabila benar dan tepat, maka ia boleh melanjutkan ke ayat berikutnya

Sedangkan untuk proses dilaksanakannya metode talaqqi dalam menghafal Alquran di TPQ Baitul Rahmah dilaksanakan setiap hari, peneliti mewawancari guru TPQ, beliau mengatakan bahwa: "Sebelum mulai mentalaqqikan surat atau ayat yang akan dihafalkan guru TPQ Baitul Rahmah mengelompokkan santri berdasarkan 
kemampuanya,jika kemampuan santri diatas rata-rata maka guru membacakan ayat yang akan dihafalkan sebanyak $3 x$ dan ayat yang di talaqqikan langsung dibacakanper ayat. Jika kemampuan santri dibawah rata-rata maka guru tidak langsung mentalaqqikan dalam 1 ayat tapi mentalaqqikannya per kata dan guru membacakan ayat yang akan dihafal sebanyak $5 x$ atau lebih sampai santri benar dalam mengucapkan ayat yang akan dihafalkan. Setelah di bagi menjadi beberapa kelompok santri duduk melingkar.Pada kegiatan ini anak harus melihat secara langsung bagaimana pengucapan huruf demi huruf yang diucapkan oleh guru. Setelah guru mentalaqqikan ayat atau surat yang ditalaqqikan santri bergiliran menyetor hafalannya."(Ibu Verawati, 23 Juli 2021)

Hal yang sama juga disampaikan oleh seorang santri yang mengatakan: "Sebelum kami menyetor hafalan ke guru, kami terlebih dahulu menghafal ayat atau surat yang akan di setorkan maupun yang akan ditalaqqikan. Guru memerintahkan kami untuk duduk melingkar sesuai dengankemampuan kami masing masing, setelah itu guru akan mentalaqqikan ayat yang akan disetorkan kepada guru. Kami harus kosentrasi melihat gerak bibirguru kalau tidak memperhatikan nanti bisa salah dalam pengucapan ayat atausurat yang akan disetorkan. Setelah merasa sudah hafal ayat atau surat yang mau di hafalkan barulah kami menyetorkan ke guru secara bergantian."(Syuhada, 30 Juli 2021)

Peneliti melihat penerapan metode talaqqi dalam menghafal Alquran di TPQ Baitul Rahmah Simpang III Palanggaran. Santri dikelompokkan berdasarkan kemampuan santri sehingga guru mengetahui kemampuan santri. Setelah duduk berkelompok dan melingkar guru mulai mentalaqqikan ayat atau huruf yang akan dihafal oleh santri, untuk santri yang memiliki kemampuan di atas rata-rata guru mentalaqqikan 3 kali dan untuk santri yang memiliki kemampuan di bawah rata-rata guru mentalaqqikan 5 kali untuk santri mereka. Untuk hafalan baru dan muroja'ah, santri yang memiliki kemampuan di atas rata-rata menyetorkan setiap hari, sedangkan siswa yang memiliki kemampuan di bawah rata-rata menyetorkan hafalan 2 kali seminggu.

Dari hasil observasi dan wawancara peneliti dengan guru dan santri mengenai kegiatan inti metode talaqqi di TPQ Baitul Rahmah maka didapatkan hasil yaitu santri di kelompokkan berdasarkan kemampuannya, santri duduk melingkar menghadap guru, dan guru membacakan ayat atau surat yang akan di hafal dan ditalaqqikan kepada santri. Bagi santri yang memiliki kemampuan di atas rata-rata maka guru akan membacakan ayat atau surat yang akan dihafalkan sebanyak tiga kali dan menyetorkannya setiap hari, bagi santri yang memiliki kemampuan di bawah rata-rata guru akan membacakan ayat atau surat yang akan dihafalkan sebanyak lima kali atau lebih dan disetorkan dua kali satu minggu kepada guru. Santri memperhatikan guru membacakan ayat atau surat keluar dari mulut guru dengan serius kemudian menyetorkan hafalan kepada guru.

\section{Evaluasi Metode Talaqqi dalam Menghafal Alquran di TPQ Baitul Rahmah Simpang III Palanggaran}

Evaluasi atau penilaian merupakan salah satu hal yang dibutuhkan dalansebuah pendidikan dan pembelajaran. Hal tersebut disebabkan pendidikan memerlukan peningkatan dimana hal tersebut dapat diukur dengan adanya penilaian.Oleh karena 
Sania dan Ahmad Kosasih: Implementasi Metode Talaqqi dalam Menghafal...

itu TPQ Baitul Rahmah melakukan penilaian pada setiap proses pembelajaran. Evaluasi atau penilaian yang dilakukan oleh guru dalam penerapan metode talaqqi dalam menghafal Alquran di TPQ Baitul Rahmah adalah dengan cara mengukur kemampuan hafalan, tajwid, dan kefasihan bacaan. Adapun proses penilaian hasil dari hafalan santri dengan memakai metode talaqqi ialah berdasarkan wawancara peneliti dengan guru TPQ Baitul Rahmah Simpang III Palanggaran yang mengatakan bahwa: "Proses penilaian metode ini dilakukan tanpa sepengetahuan santri, santri dipanggil satu-satu untuk menyetorkan hafalannya. Pada proses ini maka terlihatlah santri yang masih terbata-bata dan santri yang sudah betul tajwid serta makhrojul hurufnya. Untuk evaluasi hafalan santri baik tingkat Alquran maupun iqro' dilakukan dalam 2x. Bedanya adalah pada tingkat Alquran dilakukan secara harian dan bulanan, sedangkan pada tingkat iqro' dilakukan $2 x$ dalam seminggu dan $1 x$ dalam sebulan. Pengevaluasian $1 x$ dalam sebulan untuk mengetahui apakah targetan yang dibuat oleh guru tercapai atau tidaknya." (Ibu Verawati, 23 Juli 2021)

Pada saat proses evaluasi metode talaqqi di TPQ Baitul Rahmah peneliti melihat bahwa para santri menyetorkan hafalannya kepada guru, ketika menyetorkanhafalan tersebut santri tidak mengetahui kalau dia sedang di nilai oleh gurunya. Untuk penyetoran hafalan ini dilakukan pada hari yang tidak ditentukan. Pada proses evaluasi guru akan mengetahui kemampuan para santri seperti santri yang masih terbata-bata dalam pengucapan huruf Alquran dan santri yang serius serta sungguhsungguh dalam menghafal Alquran.

Berdasarkan hasil wawancara dan observasi yang peneliti lakukan maka didapatkan hasil bahwa evaluasi hafalan santri baik tingkat Alquran maupun iqro' dilakukan dalam 2x. Bedanya adalah pada tingkat Alquran dilakukan secara harian dan bulanan, sedangkan pada tingkat iqro' dilakukan dua kali dalam seminggu dan satu kali dalam sebulan. Kemudian santri menyetorkan hafalan dan dipanggil secara acak.

\section{Faktor Penghambat dan Pendukung Implementasi Metode Talaqqi dalam Menghafal Alquran di TPQ Baitul Rahmah Simpang III Palanggaran}

Untuk mengetahui apa saja faktor penghambat dan pendukung dalam proses menghafal Alquran menggunakan metode talaqqi di TPQ Baitul Rahmah SimpangIII palanggaran maka peneliti melakukan wawancara dan observasi. Peneliti mewawancari guru TPQ, beliau mengatakan: "Untuk faktor penghabatnya sendiri yaitu susahnya santri dalam mengontrol kosentrasinya, dukungan dari orang tua yang minim sehingga santri tidak terlalu mementingkan mempelajari ataupun menghafal Alquran, dari lingkungan juga tidak terlalu memberi dorongan untuk keberlangsungan pembelajaran yang ada di TPQ ini. Sarana dan prasarana yang tidakmencukupi juga menghambat keberlangsungan pembelajaran sehingga motivasi santri untuk belajar dan menghafal Alquran tidak begitu maksimal."(Ibu Verawati, 23 Juli 2021)

Selanjutnya Ibu Verawati juga menjelaskan tentang faktor pendukung terlaksananya metode talaqqi dalam menghafal Alquran di TPQ Baitul Rahmah, beliau mengatakan: "Faktor pendukung dari metode ini ialah semangat para santri yang ingin pempelajari dan menghafal Alquran yang sangat tinggi walaupun dukungan dari keluarga dan lingkungan tidak terlalu bagus. Faktor pendukung lainnya yaitu adanya dorongan dari guru TPQ yang mengajarkan para santri untuk mempelajari dan menghafal Alquran. Guru bertambah semangat mengajarkan santri 
saat melihat para santri bersungguh-sungguh untuk mempelajari dan menghafal Alquran. Santri di TPQ Baitul Rahmah lebih menyukai pembelajaran dengan cara guru menyampaikan secara langsung kepada santrinya tentang ayat atau surat yang akan dihafalkan dengan benar dengan duduk berhadapan sehingga lebih memudahkan keberlangsungan pembelajaran menghafal Alquran dengan metode talaqqi ini."

Pada saat observasi peneliti melihat ada beberapa faktor penghambat dan pendukung dalam terlaksananya metode talaqqi dalam menghafal Alquran di TPQ Baitul Rahmah. Faktor penghambatnya seperti sarana dan prasarana yang tidak mencukupi, lingkungan yang masih minim tentang pengetahuan mempelajari Alquran, para santri yang main-main ketika guru membaca ayat yang akan dihafalkan. Faktor pendorong dalam menghafal Alquran dengan metode talaqqi ialah semangat para santri dalam melaksanakan pembelajaran yang sangat tinggi walaupun main-main tetapi mereka memiliki keinginan yang tinggi untuk menghafal Alquran yang membuat guru lebih bertambah semangat mengajarkan santri untuk menghafal Alquran.

Dari hasil observasi dan wawancara dengan guru TPQ Baitul Ramah tentangfaktor penghambat dan pendukung terlaksananya metode talaqqi dalam menghafal Alquran maka didapatkan hasil sebagai berikut: Faktor penghambat dari metode talaqqi dalam menghafal Alquran di TPQ Baitul Rahmah yaitu kurangnya sarana dan prasarana yang ada di TPQ Baitul Rahmah, kerjasama lingkungan dengan TPQ Baitul Rahmah yang minim, dan konsentrasi santri yang masih susah dikendalikan.

Faktor pendukung dari metode talaqqi dalam menghafal Alquran di TPQ Baitul Rahmah yaitu media yang digunakan mudah dipahami oleh santri karena berhadapan langsungdangan guru dan melihat langsung cara guru dalam pengucapan huruf yang ada dalam Alquran, semangat para santri dalam menghafal Alquran yang tinggi, dan bantuan dari orang tua untuk memuroja'ah hafalan santri.

\section{Simpulan}

Pelaksanaan metode talaqqi dalam menghafal Alquran di TPQ Baitul Rahmah Simpang III Palanggaran Kabupaten Padang Pariaman ialah santri berdoa terlebih dahulu sebelum mulainya pembelajaran, santri duduk melingkar dan berhadapan langsung dengan guru, guru membacakan ayat Alquran yang akan dihafalkan oleh santri dengan baik dan benar, santri memperhatikan huruf yang keluar dari mulut guru secara langsung dan mempraktekkannya, setelah menghafal ayat Alquran dengan baik dan benar santri menyetorkan hafalannya kepada guru.

Evaluasi metode talaqqi dalam menghafal Alquran di TPQ Baitul Rahmah Simpang III Palanggaran Kabupaten Padang Pariaman ialah guru memanggil santri secara acak untuk menyetorkan hafalannya, penilaian dilakukan tanpa sepengetahuan santri,penyetoran hafalan untuk santri yang Alquran dilakukan setiap hari dan santri yang masih iqro' menyetorkan hafalannya 2x seminggu.

Faktor penghambat dan pendukung implementasi metode talaqqi dalam menghafal Alquran di TPQ Baitul Rahmah Simpang III Palanggaran ialah kurangnya sarana dan prasarana yang ada di TPQ Baitul Rahmah, kerjasama lingkungan dengan TPQ Baitul Rahmah yang minim, kosentrasi santri yang masih susah dikendalikan, dan dukungan dari orang tua yang acuh tak acuh kepada anaknya tentang pentingnya mempelajari Alquran. Faktor pendukung dari metode talaqqi dalam menghafal 
Sania dan Ahmad Kosasih: Implementasi Metode Talaqqi dalam Menghafal...

Alquran di TPQ Baitul Rahmah yaitu media yang digunakan mudah dipahami oleh santri karena berhadapan langsung dangan guru dan melihat langsung cara guru dalam pengucapan huruf yang ada dalam Alquran, semangat para santri dalam menghafal Alquran yang tinggi, serta juga bantuan dari orang tua untuk memuroja'ah hafalan santri.

\section{Referensi}

Ash-Shaabuniy, Ali Muhammad.1998. Studi Ilmu Alquran. Bandung: CV Pustaka Setia.

Awaludin, Iqbal. 2017 "Pelaksanaan Pembelajaran dan Tahsin Tahfidz dengan Metode Talaqqi di SMP Muhammadiyah 8 Surakarta Tahun Pelajaran 2016/2017". Skripsi, Surakarta.

Chotimah, Fitriani Chusnul. 2016 "Metode Pembelajaran Tahfidz Al-Qur"an di pondok Pesantren Huffadzil Qur"an Fadlulloh Kuripan Kidul Kesugihan Cilacap".Skripsi, Purwokerto.

Imana, Yudi. 2009. Sudah Baik dan Benarkah Bacaan Alquranku? Bandung: Khazanah Intelektual.

Imamah, Annisatun. 2018. Penggunaan Metode Yadain dalam Menghafal Al-Qur"an di Pondok Pesantren Miftahul Huda Siwatu Bumiroso Kecamatan Watumalang Kabupaten Wonosobo. IAIN Purwokerto.

Maharani, Yosina. 2018. "Implementasi Metode Talaqqi dalam Program Tahfidz AlQur'an Juz 29, 30 di MI Muhammadiyah Program Khusus Kenteng Nogosari Boyolali". Skripsi, Surakarta.

Mashud, Imam. 2019 "Meningkatkan Kemampuan Setoran Hafalan Melalui Metode Talaqqi Pada Siswa Kelas VIB Sekolah Dasar Islam Yakmi Pada Tahun 2018". Jurnal Penelitian dan Pendidikan dan Pengajaran. Volume 03 No 2. (April)

Poerwadarminta. 1999. Kamus Umum Bahasa Indonesia. Jakarta: Balai Pustaka. Supandi. 2014. Ulumul Qur'an. Sukoharjo: Efude Press.

Qawi, Abdul. 2017. Peningkatan Prestasi Belajar Hafalan Alquran Melalui Metode Talaqqi di MTsN Gampong Teungoh Aceh Utara. Islam Futura, Vol. 16, No.2.

Susianti,Cucu. 2016. "Efektivitas Metode Talaqqi dalam Meningkatkan Kemampuan Menghafal Anak Usia Dini”, Jurnal Tunas Siliwangi, Volume 2 No. 1, (April). 119.

Tafsir, Ahmad. 1995. Metodologi Pengajaran Agama Islam. Bandung: Remaja Rosda Karya.

Wijaya, Ahsin. 2008. Bimbingan Praktis Menghafal Alquran. Jakarta: Amzah.

Yunus, Mahmud. 2007. Kamus Arab Indonesia. Ciputat: Mahmud Yunus Wa Dzurriyyah.

Wawancara dengan Ibu Asmah pada Tanggal 31 Juli 2021 Wawancara dengan Syuhada pada Tanggal 30 Juli 2021 Wawancara dengan Ibu Verawati pada Tanggal 23 Juli 2021. 